\title{
Description of the larva of Bromeliagrion rehni (Odonata: Coenagrionidae) with bionomic notes concerning its phytotelmic habitat in central Amazonas, Brazil
}

\author{
Sharlene R. da S. Torreias ${ }^{\text {; }}$ Ulisses G. Neiss ${ }^{1}$; Neusa Hamada ${ }^{1}$; Ruth L. Ferreira-Keppler ${ }^{1} \&$ \\ Frederico A.A. Lencioni ${ }^{2}$
}

\begin{abstract}
${ }^{1}$ Divisão de Curso de Entomologia, Coordenação de Pesquisas em Entomologia, Instituto Nacional de Pesquisas da Amazônia. Caixa Postal 478, 69011-970 Manaus, Amazonas, Brasil.

E-mail: roberta_torreias@hotmail.com; ulisses.neiss@gmail.com; nhamada@inpa.gov.br; ruth@inpa.gov.br

2 Pesquisador autônomo. Rua dos Ferroviários 55, Jardim Mesquita, 12300-000 Jacareí, São Paulo, Brasil.

E-mail: odonata@zygoptera.bio.br
\end{abstract}

\begin{abstract}
The last-stage larva of Bromeliagrion rehni Garrison in De Marmels \& Garrison, 2005 is described and illustrated and bionomics and habitat information on this species are provided. The study was conducted in the Reserva Florestal Adolpho Ducke, located near Manaus, state of Amazonas, Brazil.Twelve samplings were done between April, 2003 and April, 2005: six in the rainy season and six in the dry season. In each sampling month, 12 bromeliads (Guzmania brasiliensis Ule, 1907, Bromeliaceae) were collected, six of which were terrestrial and six epiphytic, yielding144 samples. A total of 75 specimens of $B$. rehni were collected. The relationship between larval B. rehni abundance and the measured environmental parameters (volume $(\mathrm{ml}), \mathrm{pH}$, season and stratum) was significant (ANCOVA, $F=5.296$, d.f. $=130, \mathrm{p}<0.001$ ). Larvae were most abundant in the rainy season ( $<<$ 0.01 ) and water volume was positively related to the abundance of $B$. rehni. Larvae of $B$. rehni can be distinguished from those of $B$. fernandezianum (the only species in the genus with described larvae) by the number of setae in the prementum and by the color of the apical region of the femur. The association of this species with phytotelmata of $G$. brasiliensis is reported here for the first time.
\end{abstract}

KEY WORDS: Aquatic insects; Guzmania brasiliensis; phytotelmata; Zygoptera.

RESUMO. Descrição da larva de Bromeliagrion rehni (Odonata: Coenagrionidae) e aspectos bionômicos relatados ao seu habitat fitotélmico na Amazônia Central, Brasil. A larva de último estádio de Bromeliagrion rehni Garrison in De Marmels \& Garrison, 2005 é descrita e ilustrada e informações bionômicas sobre seu hábitat são apresentadas. O estudo foi conduzido na Reserva Florestal Adolpho Ducke, localizada em Manaus, Amazonas, Brasil. Entre abril de 2003 e abril de 2005, foram realizadas 12 amostragens, seis no período chuvoso e seis no seco. Para cada amostragem, 12 bromélias de Guzmania brasiliensis Ule, 1907 (Bromeliaceae) foram analisadas, seis terrestres e seis epífitas, totalizando 144 amostras. Um total de 75 espécimes de $B$. rehni foi coletado. A relação entre a abundância das larvas e os parâmetros ambientais mensurados (volume $(\mathrm{ml}), \mathrm{pH}$, estação e estratificação) foi significativa (ANCOVA, $F=5,296$, df =130, p < 0,001). Larvas foram mais abundantes na estação chuvosa ( $p<0,01)$ e o volume de água foi positivamente correlacionado com a abundância de $B$. rehni. A larva de B. rehni pode ser diferenciada da larva de B. fernandezianum, única espécie do gênero com larva descrita, pelo número de setas no premento e pelo padrão de coloração na região apical do fêmur. Pela primeira vez é reportada a associação dessa espécie com fitotelmata de Guzmania brasiliensis.

PALAVRAS-CHAVE. Fitotelmata; Guzmania brasiliensis; insetos aquáticos; Zygoptera.

Bromeliagrion De Marmels in De Marmels \& Garrison, 2005 was recently proposed by DE MARMELS \& GARRISON (2005), after a revision of Leptagrion Selys, 1876 in Venezuela. In this same paper, Leptagrion beebeanum Calvert, 1948 and Leptagrion fernandezianum Rácenis, 1958 were transferred to this new genus and a new species (Bromeliagrion rehni Garrison in De Marmels \& Garrison, 2005) was described based on specimens from Ecuador.
The three species of Bromeliagrion have limited distributions in South America: B. beebeanum is known from Guyana and Venezuela, B. fernandezianum from Venezuela, and B. rehni from Brazil and Ecuador (DE MARMELS \& GARRISON 2005) and based on specimens collected by the senior author of this paper in Brazil (LENCIONI 2006). According to DE MARMELS \& GARRISON (2005), species of this genus are probably specialized in phytotelmata of 
bromeliads. Only the larva of $B$. fernandezianum was described based on reared specimens collected in an epiphytic bromeliad of the genus Aechmea Ruiz \& Pavon (De Marmels 1985).

Bromeliaceae plants are distributed predominantly in the Neotropical region and include approximately 56 genera and more than 3,000 species (Leme \& Marigo 1993, Luther 2004). In the Reserva Florestal Adolpho Ducke, located in Manaus (Amazonas, Brazil), 13 species distributed in seven genera were listed by Ribeiro et al. (1999) and, for the Amazon region as a whole, 284 species in 22 genera were listed by BERRY et al. (1997). Many Bromeliaceae species are able to accumulate rainwater in tanks formed by the base of the leaves. Therefore, they can be categorized as phytotelms. This represents a unique aquatic habitat and sustains a characteristic fauna, which can be highly specific (Frank 1983). Moreover, abiotic factors, such as water volume within microhabitats or resource availability, may affect the presence, richness and, abundance of insect communities in phytotelms (Srivastava \& LaWton 1998, FincKe 1999, Richardson et al. 2000). One of the first detailed studies on Odonata larvae inhabiting Bromeliaceae was done in Costa Rica by CALVERT (1911), who described the habitat and the larvae of Mecistogaster modesta Selys, 1860 (Pseudostigmatidae). In Brazil, several papers have reported the association of Coenagrionidae with phytotelms of bromeliads (e.g., SANTOS 1961, 1962, 1966, 1968, 1979, 1984).

The objectives of the present study are to describe the ultimate stadium larva of $B$. rehni, to provide bionomic information about the species and to describe its association with the phytotelm of Guzmania brasiliensis Ule, 1907 (Bromeliaceae) in the Amazon region of Brazil.

\section{MATERIAL AND METHODS}

The study area is in the Reserva Florestal Adolpho Ducke (RFAD), located at km 26 of Highway AM 010 (02 55'51"S, 59 58'59”W), Manaus, state of Amazonas, Brazil. The RFAD has an area of $100 \mathrm{~km}^{2}$ and is composed mainly of upland forest. The weather in the region is equatorial humid, with mean annual precipitation of $2,362 \mathrm{~mm}$, mean annual temperature of $26.7^{\circ} \mathrm{C}$ and mean annual relative humidity of $82 \%$ (FIsCH et al. 1998). In central Amazonas, two seasons can be defined based on precipitation: a rainy season (above $200 \mathrm{~mm}$ per month), usually between November and May, and a dry season (below $200 \mathrm{~mm}$ per month), usually between June and September (Marques-Filho et al. 1981).

The sampled population of G. brasiliensis is located in a "campinarana", which is an oligotrophic type of vegetation characteristic of topographically low-altitude plateaus with sandy soils (Ribeiro et al. 1999). "Campinaranas" are known for their high accumulation of litter. The canopy is partially closed in this type of vegetation, providing high luminosity. Trees usually are 15 to $25 \mathrm{~m}$ high and harbor a high diversity of epiphytes and terrestrial bromeliads (Ribeiro et al. 1999).

Twelve samplings were done between April 2003 and April 2005: six in the rainy season (April, May and June, 2003; March,
2004; March and April, 2005) and six in the dry season (August, September and October, 2003; August, September and October, 2004). In each sampling month, 12 bromeliads of $G$. brasiliensis, six terrestrial and six epiphytic (height between 1 and $3 \mathrm{~m}$ ), were collected, for a total of 144 samples. Samples were collected with stratification into two height categories to determine if there are differences in the number of collected specimens in the phytotelms (Yanoviak 1999, Melnychuk \& SRIvastava 2002). To characterize the habitat, water volume $(\mathrm{ml}), \mathrm{pH}$ and temperature $\left({ }^{\circ} \mathrm{C}\right)$ were measured in each bromeliad. Data on atmospheric temperature and pluviometric precipitation were provided by the experimental station of the Empresa Brasileira de Pesquisas Agropecuárias (EMPRAPA-AM), located on Highway AM 010 at $\mathrm{km} \mathrm{30}$, and was used to characterize the seasonal period.

In the field, the water from each bromeliad was poured into a plastic container and transported in an icebox to the rearing facility located in the Coordenação de Pesquisas em Entomologia, Instituto Nacional de Pesquisas da Amazônia (INPA), Manaus. Large larvae, considered to be in the penultimate or ultimate stadium, were maintained alive individually in styrofoam boxes $(15 \times 15 \times 13 \mathrm{~cm})$. They fed on Culicidae larvae until the adults emerged.

Illustrations and measurements were made using either a dissecting or a compound microscope with a drawing chamber and a micrometric ocular (or eyepiece). The larval description was based on three last-instar female larvae and on the exuviae of five male and three female adults that emerged in the laboratory $(\mathrm{n}=11)$. The mandibular formula was determined according to WaTSON (1956).

Two males of recently emerged specimens of B. rehni were sent to F.A.A. Lencioni for the identification and these specimens were deposited in his private collection, all other examined specimens were deposited in the Coleção de Invertebrados, INPA, and voucher specimens of G. brasiliensis were deposited in the INPA Herbarium, both located in Manaus, Amazonas, Brazil.

An analysis of covariance (ANCOVA, $\mathrm{p}<0.01$ ) was used to determine if any relationship exists between the Odonata larval abundance in the two seasons (rainy and dry), the two sampled strata (terrestrial and epiphytic) and the abiotic factors ( $\mathrm{pH}$ and water volume). The larval abundance was $\log _{10}(\mathrm{x}+1)$-transformed and the water volume was $\log _{10}$-transformed to approximate normality. Atmospheric temperature and water temperature were not used in the analysis because these factors are highly variable over the course of the day (FINCKE 1999). Only bromeliads containing water were used in the analyses.

\section{RESULTS AND DISCUSSION Bromeliagrion rehni Garrison, 2005 Figs 1-12}

\section{Ultimate stadium larva}

Female and male thin (Figs 1 and 2) with dark-brown thorax and yellowish-brown abdomen and legs. Head: about 1.76 times as wide as long; light brown color; concave occiput in 


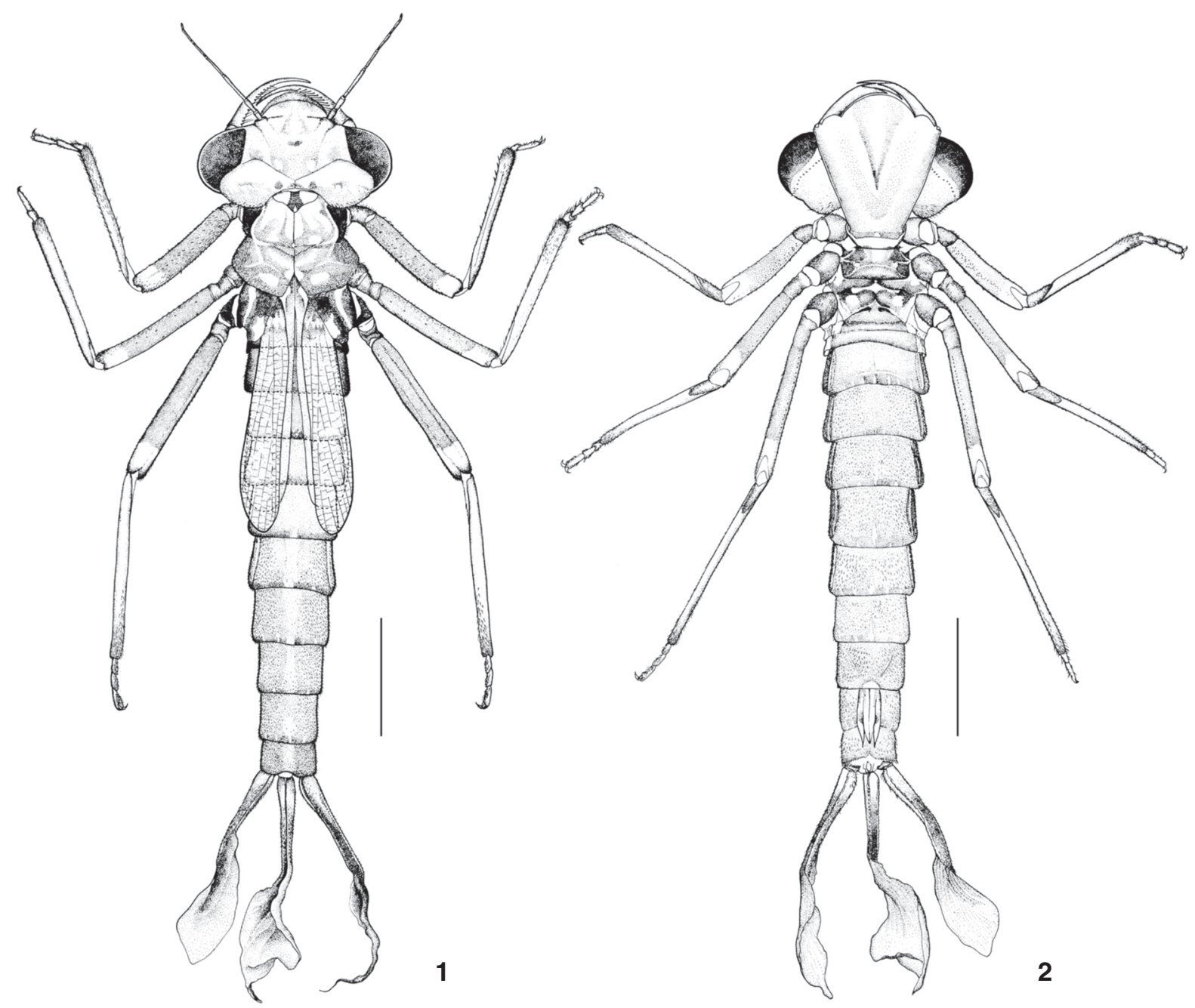

Figures 1-2. Bromeliagrion rehni, female, ultimate stadium larva: (1) dorsal view; (2) ventral view. Scale bar: $2.5 \mathrm{~mm}$.

dorsal view; cephalic lobules rounded, with a group of spiniform setae on the posterior margin. Compound eyes prominent with internal occipital margin curved medially. Anterior margin of labrum with several setae along its length. Antennae 7-segmented, yellowish-brown uniform in coloration; antennomeres I-VI with very small setae on the distal margin. Antennomere III the longest and the VII the shortest (Fig. 10). Length of antennomeres I-VII (mm): 0.21, 0.25, 0.60, 0.46, 0.41, 0.21, 0.10. Mandibles with the following formula: L 11'2+34 y abc-; R 11' 234 y a (Figs 6 and 7). Maxillae (Fig. 4) with four long and curved teeth, and two small teeth ventrally in the apical region; internal margin covered with setae. Labium prementum/postmentum articulation surpassing base of fore legs; prementum short, slightly concave, almost as wide as long (0.82 times as wide as long), with 2 to 4 (mean $=3, \mathrm{n}=11$ ) setae on each side (Fig. 3); half of distal external margin armed with row of small spines (variation of 12 to 16 , mean $=13.8, \mathrm{n}=11$ ); ligula strongly con- vex and rounded (Fig. 3), very slightly crenulated, without median cleft. Labial palps with 11 to 13 (mean $=12, \mathrm{n}=11$ ) setae, as long as double the palp width; palp, internal and external margin, glabrous (Fig. 5); two sharp terminal teeth, the inferior longer and with the apex slightly curved (Fig. 5); movable hooks well developed and apex slightly curved. Thorax: prothorax without setae and prominent angles. Fore wing pads reaching half the length of abdominal segment $\mathrm{V}$; hind wing pads reaching the posterior limit of abdominal segment V (Fig. 1). Legs light brownish; femora slightly flattened and with small spines and setae along the dorsal and ventral carina; prothoracic femora with spines on the anteroventral margin; distal region of femora of all legs colorless, forming a pale band, very evident in the median and hind legs (Figs 1 and 2). Tibia apex and ventral region of tarsi with groups of trifid setae (Fig. 8) ventrally, unpatterned; specimen drawn (Figs 1 and 2) with tarsi of the right fore leg and left median leg bi-articulated, the other tarsi 

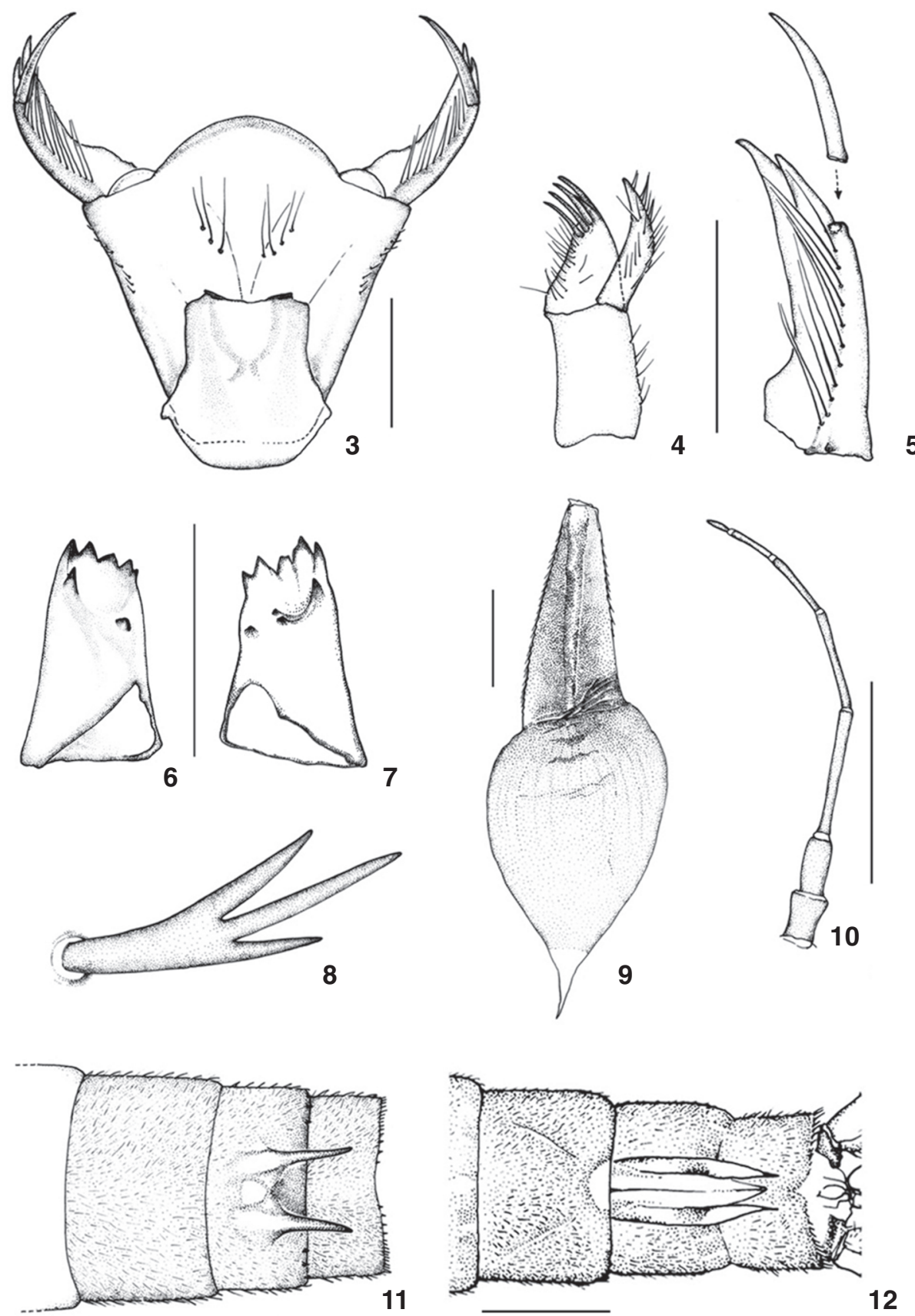

Figures 3-15. Larval details of Bromeliagrion rehni, male and female, ultimate stadium larva: (3) labium dorsal view; (4) right maxilla; (5) right labial palp; (6) right mandible; (7) left mandible; (8) trifid spine, found in ventral region of all tibia apices and all tarsi; (9) right lateral gill; (10) antenna; (11) abdominal segments VII-X, male gonapophyses, ventral view; (12) abdominal segments VII-X, female gonapophyses, ventral view. Scale bar: $1 \mathrm{~mm}$.

tri-articulated (variation observed in more than one specimen, unpatterned); tarsal claws sharp and curved. Abdomen: without dorsal or lateral spines and protuberances; uniform coloration and with minute setae in all the segments. Segment $X$ with pos- terior dorsal margin slightly elevated and with small median concavity, due to the presence of the median gill. Female gonapophyses well developed, surpassing slightly the middle of segment $\mathrm{X}$, rigid, external lobes, with setae on the lateroventral 
region and strong constriction near its mid point, ending in a pointed projection (Fig. 12). Male gonapophyses long and pointed reaching the middle of abdominal segment X (Fig. 11), in lateral view, curved toward dorsal region; basal region of each lobe with few small ventral setae. Caudal lamellae with a welldeveloped basal petiole, dark brown to lilaceous-black, with spiniform setae on the dorsal and ventral margins and in the main tracheal branch; distal region membranous and leafshaped, less pigmented than the petiole; apex pointed and transparent (Fig. 9); median lamellae with color and shape similar to the laterals.

Measurements (mm). Larval size (based on one female): 12.1 (without gills); head: length: 2.1 , width: 3.8 ; antennae: 2.3; prementum: length: 2.9 , width: 2.4 ; wing pads: anterior: 4.4 , posterior: 4.45; femora: F1: 1.9; F2: 2.5; F3: 2.9; tibiae: T1: 2.6; T2: 2.8; T3: 3.1; abdomen: length: 7.8, maximum width (segment II): 1.73 ; lateral gill: length: 4.9 , maximum width: 1.6.

Examined material. BrazIL, Amazonas: Manaus (Reserva Florestal Adolpho Ducke, 0255'51"S, 5958'59”W), all larvae collected in G. brasiliensis (Bromeliaceae): 1 female (ultimate stadium larvae), 01.VI.2003, Torreias, S.R.S., Silva, J.O., Vidal, J. legs.; 2 females (ultimate stadium larvae), 03.IV.2005; 1 male (penultimate stadium larvae), 13.IV.2005, Torreias, S.R.S.; Silva, J.O. legs.; 3 males, 3 females (emerged in laboratory), 07.IX.2004, Torreias, S.R.S., Vidal, J. leg.; 1 male (emerged in laboratory), 12.V.2005, Torreias, S.R.S., Fernandes, J.C.B. leg.; 1 male (emerged in laboratory), 31.VIII.2004, Torreias, S.R.S.; Silva, J.O. leg.

Remarks. The larvae of B. rehni can be distinguished from those of $B$. fernandezianum, the only species in the genus with described larvae, by the number of setae in the prementum and by the color of the apical region of the femur. B. rehni larvae have, in general, three setae on each side of the prementum and a pale band on the apical region of all femora (Figs 1 and 3), whereas $B$. fernandezianum larvae have just one seta on each side of the prementum and do not have the pale band on the apical region of the femora (DE MARMELS 1985). The strong constriction in the proximal region of the lamellae in B. rehni is a character that is also evident in larvae of Pseudostigmatidae. However, $B$. rehni larvae have caudal lamellae with apex very pointed and setae in the prementum, in contrast to Pseudostigmatidae larvae, which have caudal lamellae with apex not as pointed, usually rounded and without setae on the prementum.

\section{Bionomics}

Of the analyzed bromeliads $(\mathrm{n}=144)$, nine $(6.3 \%)$ did not contain water, whereas 33 (23\%) had B. rehni larvae. A total of 75 specimens of $B$. rehni were collected. One to eight specimens occurred per bromeliad, including larvae of different stadia in the same plant. A total of 22 larvae were kept alive in the laboratory, but only eight reached the adult stage (5 males, 3 females).

Table I shows the number of larvae, mean water volume, $\mathrm{pH}$ and temperature in the bromeliad, and the mean values of environmental temperature and total rainfall in each sampling period. B. rehni larvae were collected in all the sampled months, except for August 2003.

The relationship between the abundance of B. rehni larvae and the measured environmental parameters was significant (ANCOVA, $\mathrm{F}=5.296, \mathrm{df}=130, \mathrm{p}<0.001$ ). However, the model explained only $14 \%$ of the variance (Tab. II). Stratification was the only factor that did not show a relationship with the number of B. rehni larvae, even though epiphytic bromeliads had more specimens than terrestrial ones (epiphytic: $\mathrm{n}=48$, mean $=0.72, \mathrm{SD}=1.45$; terrestrial: $\mathrm{n}=27$, mean $=0.38$, $\mathrm{SD}=0.92$ ).

Larvae were more abundant in the rainy season than in the dry season $(p<0.01)$. The total number of larvae and the water volume collected in the bromeliads in the rainy season were $56(74.7 \%)$ and $8.975 \mathrm{ml}$ (57\%), whereas the corresponding values for the dry season were $19(25.3 \%)$ and $6.738 \mathrm{ml}$ (43\%), respectively.

In the sampled bromeliads, the $\mathrm{pH}$ varied from 3.9 to 6.9 (mean $=4.8, \mathrm{SD}= \pm 0.63, \mathrm{n}=135$ ), being the lowest values observed in the dry season (Tab. I). Although the number of $B$. rehni larvae was associated with high $\mathrm{pH}(\mathrm{p}=0.012)$, several studies have reported that this parameter does not have a strong influence on the organisms in phytotelmic habitats, given that they are highly specialized and can tolerate wide variation in chemical conditions of the water (LAessle 1961, Fincke 1999, YANOVIAK 1999).

Water volume was positively related with the abundance of B. rehni $(\mathrm{p}<0.01)$, corroborating other studies on Odonata that use phytotelmic habitats (FIncke 1999, Melnychuk \& SRIVASTAVA 2002). In bromeliads, as in other phytotelmic habitats, the increase in the water volume and the persistence of the water are essential factors in maintaining the aquatic community in these systems. The size of the habitat and the amount of water from precipitation, for example, are important in determining how much water and organic matter enter the system (SoTA 1996), determining the richness and abundance of the invertebrates in the phytotelms (Frank 1983, Lounibos 1983, SrivastaVA \& LAWTON 1998, Armbruster et al. 2002, Ospina-Bautista et al. 2004). In the present study, the higher number of larvae collected in the rainy season can be related to the larger amount of water in the bromeliads (Tab. I). Also, for some phytotelm colonizers, larger volumes of water are an indication that the habitat has a lower probability of desiccation, allowing the deposited eggs there to find a favorable environment for the development of the immature stages (KiTching 2000). The increase in the water volume can also increase the available microhabitats in the bromeliads (Frank 1983, Ospina-BAUTISTA et al. 2004).

The fact that more larvae were collected in the rainy season can also be related to the life cycle of the species and the flight period of the adults over the course of the year. The majority of the larvae collected in the rainy season (March, April, 
Table I. Sampling date (month/year), atmospheric temperature $(\mathrm{Ta})$ and monthly precipitation $(\mathrm{P})$ in the studied area during the collection period. Number $(\mathrm{N})$ of Bromeliagron rehni larvae collected in Guzmania brasiliensis located in different strata, epiphytic (E) and terretrial $(\mathrm{T})$, and phytotelmic mean ( \pm standard deviation) water volume $(\mathrm{ml}), \mathrm{pH}$ and temperature, in Reserva Florestal Adolpho Ducke. ( $\left.{ }^{*}\right)$ Rainy season, $\left({ }^{* *}\right)$ dry season.

\begin{tabular}{|c|c|c|c|c|c|c|c|c|}
\hline \multirow{2}{*}{ Month } & \multirow{2}{*}{$\mathrm{Ta}\left({ }^{\circ} \mathrm{C}\right)$} & \multirow{2}{*}{$P(\mathrm{~mm})$} & \multicolumn{5}{|c|}{ G. brasiliensis } & \multirow{2}{*}{$\frac{\text { B. rehn }}{\mathrm{N}}$} \\
\hline & & & Stratum & $\mathrm{n}$ & Volume (ml) & $\mathrm{T}\left({ }^{\circ} \mathrm{C}\right)$ & $\mathrm{pH}$ & \\
\hline \multirow[t]{2}{*}{ April/2003* } & $27.2 \pm 1.2$ & 386.3 & $E$ & 6 & $195.0 \pm 55.8$ & $27.0 \pm 0.6$ & $6.0 \pm 0.6$ & 11 \\
\hline & & & $\mathrm{T}$ & 6 & $228.3 \pm 112.8$ & $27.2 \pm 0.4$ & $5.5 \pm 0.5$ & 0 \\
\hline \multirow[t]{2}{*}{ May/2003* } & $27.1 \pm 1.2$ & 323.0 & $E$ & 6 & $108.3 \pm 37.6$ & $26.8 \pm 0.4$ & $5.1 \pm 0.3$ & 1 \\
\hline & & & $\mathrm{T}$ & 6 & $230.0 \pm 73.6$ & $27.4 \pm 0.5$ & $5.6 \pm 0.3$ & 5 \\
\hline \multirow[t]{2}{*}{ June/2003* } & $27.4 \pm 0.8$ & 168.8 & $\mathrm{E}$ & 6 & $175.0 \pm 236.1$ & $27.0 \pm 0.0$ & $4.9 \pm 0.2$ & 14 \\
\hline & & & $\mathrm{T}$ & 6 & $108.3 \pm 58.5$ & $27.2 \pm 0.4$ & $5.2 \pm 0.2$ & 7 \\
\hline \multirow[t]{2}{*}{ March/2004* } & $26.7 \pm 0.9$ & 462.8 & $\mathrm{E}$ & 6 & $114.0 \pm 58.6$ & $28.6 \pm 0.5$ & $5.2 \pm 0.8$ & 1 \\
\hline & & & $\mathrm{T}$ & 6 & $131.0 \pm 81.0$ & $27.8 \pm 0.4$ & $5.1 \pm 0.6$ & 2 \\
\hline \multirow[t]{2}{*}{ March/2005* } & $27.0 \pm 0.9$ & 437.6 & $\mathrm{E}$ & 6 & $76.0 \pm 46.2$ & $27.8 \pm 0.4$ & $4.5 \pm 0.4$ & 2 \\
\hline & & & $\mathrm{T}$ & 6 & $66.7 \pm 37.6$ & $28.0 \pm 0.8$ & $4.5 \pm 0.5$ & 8 \\
\hline \multirow[t]{2}{*}{ April/2005* } & $27.6 \pm 0.6$ & 474.0 & $E$ & 6 & $56.3 \pm 47.3$ & $27.7 \pm 0.9$ & $4.5 \pm 0.5$ & 3 \\
\hline & & & $\mathrm{T}$ & 6 & $67.5 \pm 24.2$ & $27.5 \pm 0.5$ & $4.6 \pm 0.4$ & 2 \\
\hline \multirow[t]{2}{*}{ August/2003** } & $28.0 \pm 0.8$ & 121.2 & $\mathrm{E}$ & 6 & $87.5 \pm 37.9$ & $27.8 \pm 0.4$ & $4.8 \pm 0.4$ & 0 \\
\hline & & & $\mathrm{T}$ & 6 & $74.2 \pm 30.1$ & $28.0 \pm 0.8$ & $4.7 \pm 0.3$ & 0 \\
\hline \multirow[t]{2}{*}{ September/2003** } & $28.4 \pm 0.9$ & 159.7 & $\mathrm{E}$ & 6 & $100.0 \pm 35.8$ & $25.0 \pm 0.0$ & $4.7 \pm 0.4$ & 2 \\
\hline & & & $\mathrm{T}$ & 6 & $74.0 \pm 25.1$ & $26.4 \pm 1.9$ & $4.4 \pm 0.6$ & 0 \\
\hline \multirow[t]{2}{*}{ October/2003** } & $28.6 \pm 1.2$ & 140.1 & $\mathrm{E}$ & 6 & $230.0 \pm 131.6$ & $27.6 \pm 0.8$ & $5.2 \pm 0.9$ & 2 \\
\hline & & & $\mathrm{T}$ & 6 & $99.2 \pm 65.3$ & $28.2 \pm 0.4$ & $4.7 \pm 0.7$ & 1 \\
\hline \multirow[t]{2}{*}{ August/2004** } & $27.8 \pm 1.1$ & 158.9 & $\mathrm{E}$ & 6 & $106.0 \pm 56.4$ & $28.0 \pm 0.7$ & $4.6 \pm 0.5$ & 4 \\
\hline & & & $\mathrm{T}$ & 6 & $95.0 \pm 72.8$ & $27.8 \pm 0.7$ & $4.6 \pm 0.5$ & 0 \\
\hline \multirow[t]{2}{*}{ September/2004** } & $28.4 \pm 1.3$ & 178.5 & $\mathrm{E}$ & 6 & $102.5 \pm 38.2$ & $27.8 \pm 0.4$ & $4.4 \pm 0.4$ & 7 \\
\hline & & & $\mathrm{T}$ & 6 & $60.8 \pm 7.4$ & $28.3 \pm 0.8$ & $4.0 \pm 0.1$ & 0 \\
\hline \multirow[t]{2}{*}{ October/2004** } & $28.8 \pm 1.0$ & 105.3 & $\mathrm{E}$ & 6 & $104.7 \pm 65.3$ & $28.0 \pm 0.6$ & $4.4 \pm 0.4$ & 1 \\
\hline & & & $\mathrm{T}$ & 6 & $69.2 \pm 52.5$ & $28.5 \pm 0.5$ & $4.4 \pm 0.4$ & 2 \\
\hline
\end{tabular}

Table II. ANCOVA results $\left(\mathrm{R}^{2}=0.140, \mathrm{~F}=5.296\right.$, d.f. $=130, \mathrm{p}<$ 0.001 ) for the dependent variable abundance of Bromeliagrion rehni $(\log 10(\mathrm{x}+1)$-transformed) and the abiotic covariates (water volume log 10 -transformed and $\mathrm{pH}$ ) and the fixed factors (season and stratum) sampled in Guzmania brasiliensis $(n=135)$, in Reserva Florestal Adolpho Ducke. ( $\beta$ ) Coefficients for the covariates, (SE) standard error, $\left.\left(^{*}\right) \mathrm{p}<0.05,{ }^{(*}\right) \mathrm{p}<0.01$.

\begin{tabular}{lccc}
\hline Covariate/Factor & $\beta$ & $\mathrm{SE}$ & $\mathrm{t}$ \\
\hline Intercept & 0.239 & 0.164 & 1.461 \\
Volume $(\mathrm{ml})^{\star *}$ & 0.247 & 0.081 & 3.043 \\
$\mathrm{pH}^{*}$ & -0.106 & 0.041 & -2.615 \\
Season $^{\star *}$ & -0.127 & 0.038 & -3.283 \\
Stratum & -0.061 & 0.036 & -1.705 \\
\hline
\end{tabular}

May, and June) were in early and intermediate stages of development, whereas in the dry season (August, September, and October), the numbers of larvae of different sizes were similar.
Studies done in the Atlantic forest in Brazil indicate that adults of Leptagrion Selys, 1876 (Coenagrionidae) show higher densities in the rainy season (SANTos 1984, De Marco \& Furieri 2000). However, additional studies on the population dynamics of $B$. rehni adults are necessary to evaluate these assertions.

The occurrence of more than one larva of Coenagrionidae per bromeliad was observed in other studies in Jamaica (LAEsSLE 1961), Brazil (SANTos 1966), and Venezuela (Lounibos et al. 1987). The presence of Odonata larvae in different stages in the same phytotelmata could increase the probability of cannibalism (FINCKE 1994). In bromeliads this factor would be reduced by the presence of microcosms formed by the structural complexity of the plant, together with leaves and small branches that could be serving as refuges for the smaller larvae (RiCHARDSON 1999).

\section{ACKNOWLEDGEMENTS}

We thank Jaílson Vidal, Jéferson O. Silva, and Janny C.B. Fernandes for help in the fieldwork. The first author received a 
fellowship from the PIBIC/INPA/CNPq/FAPEAM program, and Neusa Hamada is a CNPq research fellow. This work was financed by the projects PIPT/FAPEAM (Assembléia de insetos em Guzmania brasiliensis Ule, (Bromeliaceae) de uma reserva de terra firme na Amazônia Central, Manaus, Brasil) and MCT/INPA/PPI (Biologia e Ecologia de Insetos Aquáticos). Deyse Queiroz made the Odonata drawings and Philip M. Fearnside reviewed the manuscript.

\section{LITERATURA CITED}

Armbruster, P.; R.A. Hutchinson \& P. Cotgreave. 2002. Factors influencing community structure in a South American tank bromeliad fauna. Oikos 96: 225-234.

Berry, P.E.; B.K. Holst; K. Yatskievych.1997. Flora of the Venezuelan Guayana, vol. 3, Araleaceae - Cactaceae. In: J.A. Steyermark; P.E. Berry; K. Yatskievych \& B.K. Holst (Eds). Flora of the Venezuelan Guayana. Missouri Botanical Garden, St. Louis, $774 \mathrm{p}$.

Calvert, P.P. 1911. Studies on Costa Rican Odonata. II. The habitats of plant-dwelling larva Mecistogaster modestus. Entomological News 22: 402-411.

De Marmels, J. 1985. La náyade de Leptagrion fernandezianum Rácenis, espécie bromelícola (Odonata: Coenagrionidae) y consideraciones sobre la possible relación filogenética del género Leptagiron Selys. Boletin de Entomologia Venezolana 4 (1): 1-8.

De Marmels, J. \& R.W. Garrison. 2005. Review of the genus Leptagrion in Venezuela with new synonymies and descriptions of a new genus, Bromeliagrion, and a new species, B. rehni (Zygoptera: Coenagrionidae). Canadian Entomologist 137 (3): 257-273.

FinCKe, A.M. 1994. Population regulation of a tropical damselfly in the larval stage by food limitation, cannibalism, intraguild predation and habitat drying. Oecologia 100: 118-127.

Fincke, A.M. 1999. Organization of predator assemblages in Neotropical tree holes: effects of abiotic factors and priority. Ecological Entomology 24: 13-23.

Fisch, G.; J.A. Marengo \& C.A. Nobre. 1998. Uma revisão geral sobre o clima da Amazônia. Acta Amazonica 28 (2): 101126.

Frank, J.H. 1983. Bromeliad phytotelmata and their biota, especially mosquitoes, p. 101-128. In: J.H. Frank \& L.P. Lounibos (Eds). Phytotelmata: terrestrial plants as host for aquatic insect communities. Medford, Plexus, 293p.

De Marco Jr, P. \& K.S. Furieri. 2000. The ecology of the bromeliad-dweller Leptagrion perlongum (Odonata: Coenagrionidae). Boletim do Museu de Biologia Professor Mello Leitão 11/12: 135-148.

Kitching, R.L. 2000. Food webs and container habitats: the natural history and ecology of phytotelmata. Cambridge, Cambridge University Press, 431p.

Laessle, A.M. 1961. A micro-limnological study of Jamaican bromeliads. Ecology 42: 499-517.

LEME, E. \& L.C. MARIGO. 1993. Bromeliads in the Brazil wilderness.
Rio de Janeiro, Ed. Marigo Comunicação Visual, 183p.

LenCioni, F.A.A. 2006. Damselflies of Brazil: an illustrated identification guide 2 - Coenagrionidae. São Paulo, All Print, VIII+419p.

Lounibos, L.P. 1983. The mosquito community of treeholes in subtropical florida, p. 223-246. In: J.H. Frank\& L.P. Lounibos (Eds). Phytotelmata: terrestrial plants as host for aquatic insect communities. Medford, Plexus, 293p.

Lounibos, L.P.; J.H. Frank; C.E. Machado-Allinson; J.C. Navarro \& P. OCANTO. 1987. Seasonality, abundance and invertebrate associates of Leptagrion siqueirai Santos in Aechmea bromeliads in venezuelan rain forest (Zygoptera: Coenagrionidae). Odonatologica 16 (2): 193-199.

Luther, H.E. 2004. An alphabetical list of bromeliad binomials. Sarasota, The Bromeliad Society International, The Marie Selby Botanical Gardens, $10^{\text {th }}$ ed., 113p.

Marques-Filho, A.O.; M.N.G. Ribeiro; H.M. Santos \& J.M. Santos. 1981. Estudos climatológicos da Reserva Florestal Ducke Manaus - AM. IV. Precipitação. Acta Amazonica (11): 759768.

Melnychuk, M.C. \& D.S. SRivastava. 2002. Abundance and vertical distribution of a bromeliad-dwelling zygopteran larva, Mecistogaster modesta, in Costa Rican rainforest (Odonata: Pseudostigmatidae). International Journal of Odonatology 5 (1): 81-97.

Ospina-Bautista, F.; J.V. Estévez-Varón; J. Betancur \& E. RealpeREBOLLEDO. 2004. Estructura y composición de la comunidad de macroinvertebrados acuáticos asociados a Tillandsia turneri Baker (Bromeliaceae) em um bosque alto andino colombiano. Acta Zoologica Mexicana 20 (1): 153-166.

Ribeiro, J.E.L. DA S.; M.J.G. Hopkins; A. Vicentini; C.A. Sothers; M.A. da S. Costa; J.M. De Brito; M.A. de Sousa; L.H.P. Martins; L.G. Lohmann; P.A.C.L. Assunção; E. DA C. Pereira; C.F. dA Silva; M.R. Mesquita \& L.C. Procópio. 1999. Flora da Reserva Ducke: guia de identificação das plantas vasculares de uma floresta de terra-firme na Amazônia Central. Manaus, Instituto Nacional de Pesquisas da Amazônia, 799p.

Richardson, B.A. 1999. The bromeliad microcosm and the assessment of faunal diversity in a Neotropical forest. Biotropica 31 (2): 321-336.

Richardson, B.A.; M.J. Richardson; F.N. Scatena \& W.H. Mcdowell. 2000. Effects of nutrient availability and other elevational changs on bromeliad populations and their invertebrate communities in a humid tropical forest in Puerto Rico. Journal of Tropical Ecology 16: 167-188.

SANTOS, N.D. 1961. Duas novas espécies do gênero Leptagrion Selys, 1876 (Odonata: Coenagrionidae). Revista Brasileira de Biologia 21 (4): 359-362.

SAntos, N.D. 1962. Fauna do Estado da Guanabara. 50. Descrição de Leptagrion perlongum Calvert, 1909, fêmea e notas sobre outras espécies do gênero (Odonata: Coenagrionidae). Boletim do Museu Nacional, Zoologia, 233: 1-8.

SANTOS, N.D. 1966. Contribuição ao conhecimento da fauna do 
Estado da Guanabara. 56. Notas sobre cenagrionídeos (Odonata) que se criam em bromélias. Atas da Sociedade de Biologia do Rio de Janeiro 10 (3): 83-85.

SANTOS, N.D. 1968. Descrição de Leptragrion siquerai sp. n. (Odonata, Coenagrionidae). Atas da Sociedade de Biologia do Rio de Janeiro 12 (3): 137-139.

SANTOS, N.D. 1979. Descrição de Leptagrion bocainense Santos, 1979 cenagrionídeo bromelícola (Odonata: Coenagrionidae). Anais da Sociedade Entomológica do Brasil 8: 167-173.

SANTOS, N.D. 1984. Odonatas que se criam em bromélias de restingas no litoral fluminense, p. 351-354. In: L.D.LACERDA; D.S.D. Araújo; R. Cerqueira \& B.C. Turce (Eds). Restingas: origem, estrutura, processos. Niterói, CEUFF, Universidade Federal Fluminense, 477p.
Smith, L.B. 1955. The Bromeliaceae of Brazil. Smithisoniam Misceleneaus Collection 126 (1): 144-157.

SoтA, T. 1996. Effects of capacity on resource input and the aquatic metazoan community struture in phytotelmata. Researches on Population Ecology 38 (1): 65-73.

SRIVASTAVA, D.S. \& J.H. LAWTON. 1998. Why more productive sites have more species: a experimental test of theory using treehole communities. The American Naturalist 116: 770-787.

WATSON, M.C. 1956. The utilization of mandibular armature in taxonomic studies of anisopterous nymphs. Transactions of the American Entomological Society 81: 155-202.

YANOVIAK, S.P. 1999. Community structure in water-filled tree holes of Panama: effects of hole height and size. Selbyana 20: 106-115.

Submitted: 30.V.2008; Accepted: 12.IX.2008.

Editorial responsibility: Gabriel Mejdalani 